\title{
Television and Recent American Fiction
}

\section{Cecelia Tichi}

Now that a generation of writers has grown up in the era of broadcast television, the medium is having a formal impact on American fiction. Television is affecting the experience of time and its representation in fiction, and changing the relation of the narrative consciousness to the external environment. All this has proved inevitable. As one study says, "People are now born into the symbolic environment of television and live with its repetitive lessons throughout life" (Gerbner et al. 442). There is even an analogous historical precedent in this century: just as the technologies of rail and automobile, dislocating ideas of time and space, contributed to modernist aesthetics, so broadcast television, widespread in the United States since the late 1940 s, now makes its presence felt in the very structure of fictional narrative. We need to examine the process by which television, long held to be inimical to the literary text, instead has come to shape fiction of the 1970s and '80s, bringing structural innovations that are not yet adequately understood.

Like any other dominant technology, television first had to move from its initial status as an alien or exotic phenomenon before it could be exploited formally in fiction. The process of its assimilation is beyond the scope of this discussion, but a few statistics suggest that the later 1950s mark the point at which the television environment was sufficiently established in the United States to engender a group of writers-to-be deeply involved with the new cognitive processes. By $1960,87.5 \%$ of all United States households had at least one TV set, a figure that climbed to $95.5 \%$ by 1970 and to $98 \%$ by 1980 (Bower 7). These figures would be even higher were public places to be included in surveys, and the percentages suggest that individuals without television in their own habitats could easily watch it elsewhere, at neighbors', friends', relatives', etc.

The proliferation of television in very recent fiction, both its apparatus and its programs, reflects this decades-long technological assimilation, and TV becomes a part of the realist author's sense of the texture of contemporary American life. 
For instance, atop a motor home, Michael Martone's narrator in a story in Safety Patrol (1988) sits "under the TV antenna cocked like a cafe umbrella" (56). "Some things you put on top of the [TV] cabinet," muses a character in Ernest Hebert's Whisper My Name (1985), "and some things you put inside" (82). "My mother read about ... a new Sony portable color television," says the narrator of Mona Simpson's Anywhere but Here (1986). "She wanted a white one" (223).

TV appears in similes as part of the novelist's effort to develop shared assumptions, as in John Updike: the children's faces "turned to the television screen like flowers to the sun" (Roger's Version 352). Unlikely characters watch it, for instance Robert Olmstead's Maine wilderness guide and trapper in Soft Water (1988) who awakens to "Sesame Street," "Mister Rogers," and "Donahue" (161). Then too, it becomes a form of stage business, serving functions previously reserved, say, for the smoking of cigarettes. A Raymond Carver character, in Cathedral, "turned off the TV and carried the glass back to the sink.... He sat down on the sofa once more.... He reached over and turned the TV on. He adjusted the volume" (114, 124). From stage business to cabinetry, the ubiquitousness of TV in novels and stories is an index of the spread of the technology in recent United States history. "Transcending historic barriers of literacy and mobility, television has become the primary source of everyday culture of an otherwise heterogeneous population" (Gerbner et al. 442).

Through these years of virtual television saturation, humanistic critics and analysts in the main have taken a nowfamiliar adversarial position toward the medium, casting their arguments in high culture/low culture terms. Typical is Ashley Montagu's 1962 reference to "the sterile puerilities which find so congenial a home in the television world" and his call, in the name of "good taste," for an abatement of its "noisome vulgarity" (132). Other critics have addressed the vexed television-literature relation more directly, as in a mid-1970s article that begins, "While untold copies of Ulysses, their pages yellowed and brittle, sit forgotten in the dark corners of bookshelves throughout the land, Magnum, P.I. surges through twenty million homes each week" (Anderson 112). Here the posited opposition between television and the literary text is rhetorically constructed to threaten those with primary commitment to the literary classic. By implication, Shakespeare too lies neglected, along with Melville, James, Stein, and untold others-not only neglected by a mass audience, but abandoned by onetime read- 
ers now content to watch TV in mass solidarity while their books crumble.

Voices from academe have joined this discussion, reinforcing the bipolar opposition between literature and television. A recent case in point is Wayne C. Booth's juxtaposition of televisual and literary texts. Television, Booth argues, makes immediate and indelible visual impressions but fails to make any "intellectual demands of the kind expected of even the most watered-down philosophical or scholarly text, or of the printed fiction that critics take seriously" (397). In an argument that recapitulates the decades-long normative stance of the literary intelligentsia, Booth identifies imaginative recreation as the hallmark of literature, in which "the action takes place in a country somehow in my head ... [and is] not confined to a box or screen" (390). Booth excoriates television for forbidding reflection, commodifying the deepest human emotions, stereotyping, presenting a specious gift of programs. His reader, not surprisingly, is required to take the side of literature while acknowledging, anxiously, the power of the encroaching televisual medium.

Extending Booth's argument further, Mark Crispin Miller now declares that the controlled commercial monopoly of the television environment has destroyed critical consciousness in the United States (285-331). We are, according to Miller, "boxed-in" and must deconstruct the television text in order to disclose its technological "degradation of experience," its debasement of "public culture," its exacerbation of racial, class, and gender-based animosities (19).

Readers of Booth and Miller may not recognize the extent to which their own structural divisions, presented as givens, cast the tenets of the argument in binary, oppositional terms. Above all, these critics, like their predecessors, construct their argument on the binary opposition between the worlds of television and literature. The epistemic premise consists of two separate and mutually exclusive worlds. Essentially, television and literature designate adversarial principles of puerility vs. maturity, low culture vs. high, entertainment vs. intellectual engagement, frivolity vs. seriousness, contamination vs. purity, robotry vs. critical imagination. These are the battle lines that have continued, uncontested, for nearly forty years. The way the argument has been cast suggests that resolution of the conflict is possible solely in one's maturation. The child held captive by the powerful popular medium will ultimately renounce TV and embrace the intellectual-imaginative complexity of the printed text. As one analyst observes, "We expect children to like tele- 
vision precisely because they are easily amused and do not know any better, but we also expect them to grow out of it" (Attallah 225). The enlightened adult can be expected to cross the oppositional boundaries, while the boundaries themselves remain intact.

Like so many conflicts, however, this one evidently is being abandoned before it is resolved - and by the very TV-generation erstwhile "children" who in the 1970s-'80s are refusing the old terms of argument. Not that the writers refuse maturity; they are not a generation of video Peter Pans. Rather, they reject the division between the worlds of television and literature. The narrator of a William Warner story remarks, without embarrassment, that "some writers [are] first trained by reading Dickens or Fitzgerald ... others by watching TV" (197). Warner, among others, rejects the position that television is alien, even inimical to the literary imagination. Such writers simply refuse those terms of engagement and the hierarchy implicit in the terms. Lawrence Wright's memoir, In the New World: Growing Up with America 1960-1984 (1988), for instance, intermixes lifelong watching of sitcoms, TV news, and Congressional hearings with avid reading of Joyce, Bellow, Percy, and Richard Wright. Altogether, these experiential references constitute the autobiographical natural world. Including television and literary texts in this way, Wright shows the newer fiction writers' preparation to exploit the cognitive traits of television in fiction. Before examining the nature of that form, however, it is helpful to see in some detail how fiction itself is now arguing that literary and TV texts are conjunctive in the contemporary American consciousness.

One recent novel, Jill McCorkle's The Cheer Leader (1986), presents at length the holistic relation of television and literary texts. It mixes the two freely, even promiscuously, to represent the contemporary consciousness of the writer. In this comingof-age novel, Joslyn (Jo) Spencer, a high school girl, bursts the cocoon of slumber parties and small-town life during a summer involvement with an older boy before she goes off to college. McCorkle's protagonist, an avid reader of classic literary texts, is perfectly positioned to expose the relation of the literary mind to the realm of commercial TV. At home in the world of books, Jo becomes a significant television test case precisely because she is not an unschooled, inarticulate character susceptible of uncritical acceptance of the medium.

In The Cheer Leader, literary and TV culture cohabit comfortably. McCorkle's protagonist is a young woman of words, an aspirant poet who reads Proust, Maupassant, Dickinson. At 
the same time, her lifelong frame of reference features television. A friend wears a bikini and "I Dream of Jeannie" pants, while a boyfriend looks "as All American as Wally Cleaver" on "Leave it to Beaver." At first sight, Jo's boyfriend-to-be does not have a "Then Came Bronson" ruggedness. "Clearly," she says in an attempt to define herself, "I am not an 'I Love Lucy' nor am I 'That Girl"' $(36,46,59,60,84,264)$. These references come interspersed with serious statements on such canonized writers as Chaucer or Plath or Sherwood Anderson or Proust. All comprise one unitary world; there is no disjunction between canonical literary and TV texts.

Moreover, television is embedded in childhood's best memories (and we doubtless can expect more of this in quasiautobiographical fiction of the foreseeable future). Jo recalls childhood wrapped in "flannel jammies," when she would "sit on the floor and let the dog chew on the fuzzy slippers that came last Christmas," and rest her head "on Daddy's knee and watch the gray TV light flicker on the knotty pine paneling, watch every fear of the day dissolve into the gray, into the hum and lullaby" (170). The maternal side of this experience is here too, the late afternoons, "the TV on, black and white, her mother ironing ... [while watching] As the World Turns while she and [her brother] Bobby eat vanilla wafers . . until . . . her mother is cooking dinner and Andy Griffith is on the TV" (182).

Projecting her future, Jo never repudiates television, never hints at its supersession. Chaucer and "I Love Lucy" exist simultaneously. They are not even juxtaposed, not set in selfconscious relation to each other. True, this kind of consciousness flattens history into one present state. But there is no irony in McCorkle's positioning, no polemic statement about high culture versus the popular. Jo is not slumming in TV reruns.

And she is not, as a poet, devotee of words, planning to put aside, much less to reject, television in adulthood. At the end of the novel, imagining marriage and a young son, to be named Anaximander, she envisions rainy days when "I will roll back my nice oriental rugs and little Anaximander and I will roller skate while we watch old reruns on TV" (265). This projection of the future will be a permutation of her own childhood experience. The fantasy is based on the presumptive pleasure of television. In the consciousness of this poet-protagonist a Greek philosopher namesake and TV reruns coexist in perfect accord. Literacy, literature, intellectual life, McCorkle argues, include popular television. The Cheer Leader is significant here precisely because it shows how TV has been naturalized and 
how it has entered the contemporary American literary consciousness.

There is a generational issue here. Not every writer who positions a television set in a fictional scene enacts the perceptual traits of the medium. The point seems obvious, its implications perhaps less so. Writers can only enact the values of a video culture from the presumption of their presence within the TV environment. Those psychologically outside of it, typically those who grew up in the years before the TV consoles, table models, and portables proliferated in American households and public places, maintain a very different relation to the medium even when they exploit it in fiction. In order to understand the ways in which younger writers from Ann Beattie onward to Bobbie Ann Mason, Bret Easton Ellis, Peter Cameron, Todd Grimson, among others, are enacting the traits of broadcast television in the very form of their fiction, it is helpful to juxtapose two texts overtly concerned with television. The two, published at about the same time, enable us to see radically different positionings of narrator and reader in television scenes of pre-TV and TVera writers. The first text is the work of John Updike, a preTV-era writer who began publishing in the mid-1950s; the other, Bobbie Ann Mason, whose fiction first appeared in the 1980s.

Roger's Version depicts the household of a Protestant theologian, Roger Lambert, whose twelve-year old son struggles with his homework in front of the TV. The narrator watches his son "crouching blurry-eyed over his math homework while trying to keep a rerun of 'Gilligan's Island' in focus," even as both parents talk and intermittently try to help him:

On "Gilligan's Island" a small man with a yelping voice was wearing a sarong and trying to avoid a heavyset blond man who, clad in a splashy-patterned bathing suit, was bombarding him with water balloons from a helicopter. ... "Gilligan's Island" momentarily yielded to a commercial. For catfood. A handsome, caramel-colored cat, an actorcat wearing a bow tie, was shown snubbing raw steak and fresh fish and then greedily burying its face up to its throat muff in a dish of gray-brown pellets. (44-48)

In this passage Updike wants it both ways, wants his narrator both to be involved and yet critically detached from the "everyday culture" of TV. He doesn't see Gilligan as a character, much less as the actor Bob Denver, but instead as a small man with a yelping voice in a sarong. Watching the commercial, 
he does not see Morris the cat but an "actor-cat." Presumably we, the readers, are seeing Gilligan and Morris, but the act of identification, of naming, is left to us, though at our peril. The two television identities are undisclosed, but not to enable us to participate in acts of discovery, acts of identification so characteristic of the implied contract between the writer and reader in fictional narrative. We are not here given indirect clues or information. Rather, Updike intends that his narrator and reader be empowered by a critical distance from the TV environment. We are supposed to be above and beyond all that. Inadvertently, Updike puts us in the realm of that binary opposition, in which our only legitimate response is a detachment that means rejection of the television world. Like the narrator, we are momentary analysts of the TV rerun and the commercial; we are cultural critics superior in our distance. Our very ignorance of the specifics of the TV names is important insofar as it establishes our qualifications as critics. To name names, to say "Gilligan" or "Morris" is to implicate ourselves in the crass, the commercial.

So we are to see a "small man with a yelping voice" and "actor-cat" instead of Gilligan and Morris. We are to suppress those names we know, lest we be complicitous with the popular culture, be mundane participants instead of cultural critics. The only tenable position, intellectually and morally, is the narrator's, authenticated by ignorance of the commercial and the popular. The right readers are a coterie who are beyond contempt for Gilligan and Morris, themselves figures so unworthy of consciousness that the proper reader can only be oblivious. So if it happens that we know their names, we must not speak them even to ourselves. The boy with the homework might do so, but not us. Our credentials as civilized adults depend upon not naming.

Unwittingly, however, Updike is caught, because he has named the program and its status as a rerun. His narrative stance really depends upon shunning commercial broadcast TV, and he risks compromising his narrative authority by being forced to admit into the discourse the very terms banished from it. Thus he all but reveals the specifics he would shudder to say, that the young man in the sarong is the immediately recognizable, familiar title character of a sitcom based on an island shipwreck, that the advertisements featuring the finicky caramel-colored cat have made the feline nationally famous. Both Gilligan and Morris are American bywords, but Updike begs to conspire with the reader not to say what he knows, or even that he knows. Bringing popular culture into the novel, Updike 
works nonetheless to distance himself and his proper reader from it.

In contrast, Bobbie Ann Mason's novel In Country (1985) repeatedly places the reader before the TV set in direct and unmediated engagement. In one scene from this post-Vietnam antiwar novel we see eighteen-year old Samantha (Sam) Hughes in a motel room with her uncle Emmett watching the "Tonight Show" in which the comedian Joan Rivers substitutes for Carson:

Joan Rivers is wearing a black taffeta job with a balloon ruffle around the hips and gobs of pearls. She says her outfit is Boy George's gym suit. She is made up pretty and blond, but she isn't really that pretty or that blond. She says it's raining in L.A. - at last Willie Nelson will get his hair washed, she says. She says he wears a Roach Motel around his neck. Her first guest is Don Rickles. Don Rickles tells Joan Rivers, "Johnny hired you because you're no threat." He says Johnny is at home posing in his swim suit and saying, "How's the body?" Don Rickles and Joan Rivers rattle back and forth about their dates in Las Vegas. Joan Rivers says a woman needs a funny face and a trick pelvis and that's all. But Don Rickles says college would be an advantage. His daughter is going to college. (19-20)

Here the narrative consciousness, Sam's, is directly involved in the televised segment, which is virtually transcribed, something of a documentary report, though not without criticism. Rivers, Sam observes, is "made up" to look pretty but "isn't really that pretty," and she and her show business guest "rattle" on about their forthcoming appearances. Readers will soon understand that the decision to go to college hangs heavily on Sam, so the Don Rickles statement about his daughter has a personal immediacy and importance.

This text, unlike Updike's, does not insinuate two classes of readers, those seduced by commercial television and those who stand above it, i.e., the pure and the contaminated of the binary opposition. Mason nowhere signals her own superiority to the program or criticizes her protagonist for any serious involvement in it. She does not patronize or condescend to her characters. Nor does she invoke a tone of satiric ignorance in order to provide her readers an exit to a promontory of critical distance from the televised scene. We hear nothing, for instance, of a self-deprecating, angular blond stand-up comic who insults other celebrities by satirizing their physical appearance. Quite 
the reverse. The privileged reader-rather like that of John Dos Passos in the 1920s and '30s - has to know the specific context of popular culture, from the name of a pest control product to the identities of Rivers, Don Rickles, Boy George, and the hardbitten Willie Nelson. The text presumes the authority of the world of commercial broadcast television. It can be reported, transcript-fashion, because it needs no explication. No distinction between the mature and the puerile hinges on knowledge or ignorance of commercial television. Mason is within the television environment and presumes that her reader is also there. And her reader is presumed to stand in the same relation to television as she herself does. Her text is at one with this world of broadcast TV as Updike's is not.

At this point we can examine the formal narrative implication of Mason's stance, one she shares with a number of contemporary TV-era writers. In fact, the ways in which television affects narrative form in the 1970s and '80s may be approached through theorists of the video medium, especially Raymond Williams, John Ellis, E. Ann Kaplan. In the mid1970s Williams, in Television: Technology and Cultural Form, cautioned that television reviewers were misguidedly, anachronistically operating like drama or film critics or book reviewers, approaching individual programs as "a discrete event or a succession of discrete events" (88). Williams, the Marxist social analyst with particular interests in the cultural institutions of print, had been a BBC television reviewer between 1968 and 1972 when he became convinced that forms of broadcasting in the TV age were altering perceptual processes. Prior to broadcasting, Williams observes, "the essential items were discrete ... people took a book or a pamphlet or a newspaper, went out to a play or a concert or a meeting or a match, with a single predominant expectation or attitude" (88). The fundamental expectation was of a discrete program or entity.

But increasingly, Williams finds, in the era of television broadcasting the discrete program has yielded to a structure far more fluid. "There has been a significant shift from the concept of sequence as programming to the concept of sequence as flow." He goes on: "there is a quality of flow which our received vocabulary of discrete response and description cannot easily acknowledge" (93).

Williams's identification of "flow" has proved a benchmark in differentiating the experience of broadcast television from other narrative forms. Conceding that vestigial elements of discrete programs remain intact in the timed units of a "show," he argues nonetheless that the intervals between these units have 
disappeared. In American broadcast television the advertisements are incorporated into the whole: "What is being offered is not, in older terms, a programme of discrete units with particular insertions, but a planned flow, in which the true series is not the published sequence of programme items but this sequence transformed by the inclusion of another kind of sequence, so that these sequences together compose the real flow, the real "broadcasting"' (90). Williams then observes that the additional, more recent insertion of trailers and previews of forthcoming broadcasts further contributes to and complicates the flow, and he calls all this "a new kind of communication phenomenon" demanding recognition (91).

Williams's demarcation of flow has been tremendously influential among scholars and analysts of video forms. Every subsequent analyst of the medium of broadcast television has addressed the concept, some with certain modification. Robert C. Allen, in his study of television soap opera, remarks that "the viewer must be encouraged not just to tune in for a single program but to submit to the 'flow' of programming throughout an entire evening" (47). E. Ann Kaplan finds that the principal kinds of programs - soap operas, prime-time dramas, news and game shows - "exist on a kind of horizontal axis that is never ending." She emphasizes that "the fixed and clearly defined boundary of the novel or Hollywood movie" is utterly different from television, which has "neither a clear boundary nor a fixed textual limit" (Rocking Around the Clock 4). John Ellis, another analyst of broadcast television, believes that Williams's definition of flow omits consideration of the precisely timed "items" or, in television workers' own parlance, "segments," all demanding "short bursts of attention." In this sense, "flow" is really segmentation without closure, something like an endless string of bright beads (116-19). However much these analysts debate the precise experience of flow, all concur that the experience of television watching is unlike that of theater or film, both of which are bounded and unitary. All uphold the essential idea of fluidity as a dominant trait of television.

Turning to a group of writers cognitively informed by this kind of flow, writers who from childhood belonged to a world which has spent untold hours watching television, the analysts of televisual form can prove heuristically helpful. Their concept of flow, applied to TV-age fiction, can help us understand the new fictional structures which otherwise draw censure for their apparent defection from form itself. By implication, Williams and others enable readers to understand that the experience of flow, enacted cognitively in fiction, makes certain formal traits 
become virtually inevitable. These will not be narratives of the beginning-middle-end structure. Flow enables entry at any point. The narrative of flow is continuous, open, apparently without end. Thus it is unsurprising that a school of fiction writers begin as if by unspoken agreement to violate a onetime cardinal rule of fiction writing, namely, that the principal fictional tense be the simple past. Instead, in the 1970s and '80s writers from every area of the United States, some of them writers with marked interests in regional material, began to cast narrative in the present tense, the tense that best enacts the experience of flow and the primacy of the present moment within it. Here is a typical opening passage, this from Ann Beattie's Chilly Scenes of Winter (1976):

\section{"Permettez-moi de vous presenter Sam McGuire," Charles says.}

Sam is standing in the doorway holding a carton of beer. Since Sam's dog died, he has been drinking a lot of beer. It is raining, and Sam's hair streams down his face.

"Hi," Susan says without looking up.

"Hi," Sam says. He takes off his wet coat and spreads it out on the rug. He goes through the living room to the kitchen and puts two six-packs in the refrigerator. Charles follows him into the kitchen.

This novel, one is made to feel, could start anywhere. It is not a version of in medias res, a concept which presupposes the Aristotelian structure of beginning-middle-end. It does not work to show symmetry and proportion as, for example, Henry James sought to do. James had worried that the "centre" of The Wings of the Dove "isn't in the middle" and that the middle was really at the end, thus structurally truncating the novel. To express his predicament, he resorts to an image of organic disharmony: "The book, in fine, has too big a head for its body." James's image reveals the depth of his concern for formal integrity, a formal symmetry that the writer could discern and, presumably, the reader, for whom it would properly measure successful fictional form. If James's image reverts to Romantic goals, we can notice that Dos Passos, the industrial machine-age novelist, was equally committed to self-evident structural integrity when he invoked the idea of design in fiction, allying himself with architecture when he called himself the architect of history. Whether referring to organic form or machine-age design, these two writers communicated the importance they attached to evident formal integrity, to discrete and bounded fictional struc- 
ture. Specific, discernible shape was crucial to their conceptions of narrative.

Ideas of the bounded text change in the television era, when the primacy of flow takes precedence. Fluidity supersedes boundary, not only in Chilly Scenes of Winter, but in fiction like Bret Easton Ellis's Less than Zero (1985), David Leavitt's “Territory" in Family Dancing (1983), Peter Cameron's “Nuptials \& Heathens" in One Way or Another (1986), Robert Olmstead's Soft Water (1988), Jill Eisenstadt's Far Rockaway (1987). Indeed, these texts do not begin; they simply start, as if turned on or come upon. The present moment may be pedestrian, as in Beattie, or dramatic, as in Olmstead, or somewhere in between (portentous in Ellis, ambiguous in Leavitt). But readers are made to feel that, instead of a beginning, there is a point of entry. We are joining a program in progress, i.e., in process. We move into a sequence of events which are to be represented in a continuous flow.

This kind of fluidity involves more than a cognitive privileging of the present, and the enactment of it in the present tense. Writers for whom broadcast television is a lifelong experience are revealing a new relation between the individual and the world, a relation which TV structures, and one based upon, but modifying, the concept of "flow." Christopher Lasch remarks that increasingly impressions of the world come, not from firsthand experience, but from "elaborate systems of communication" which present simulacra of reality (133). The fictional texts tell us something of the contemporary response to that situation and suggest the defenses enacted against it. For television paradoxically divides and multiplies centers of consciousness as the viewer phases in and out of the onscreen TV worlds, all the while adjusting and readjusting to the shifting context of the surroundings.

We can better see this sojourning in another fictional representation, Betsy Byars's novel for children, The TV Kid (1976). Here the reader enters directly into the mind of eleven-year old Lennie, who lives with his mother at a motel she owns and runs. As the novel opens, he is hosing down a walk, reminded by his mother that his homework (again, homework, the world of abstract symbols and literacy) must be done:

“Aren't you through yet?" Lennie's mother called. You've got to do your homework, remember?" ...

Lennie walked on to the office. As he went inside, he paused in front of the TV.

A game show was on, and there were five new cars 
lined up on a revolving stage. The winning contestant got to pick one of the cars, and if it started, he got to keep it. Only one of the cars was wired to start.

"It's the Grand Am," Lennie said instantly. He felt he had a special instinct for picking the right box or door or car on shows like this. "I know it's the Grand Am."

"Lennie, are you watching television?" his mother called from the utility room.

"I'm looking for a pencil," he called back.

"Well, there are plenty of pencils on the desk."

"Where? Oh, yeah, I see one now."

Lennie was hoping to stall until he could see if it really was the Grand Am as he suspected.

The contestant wanted to try for the Catalina. "No, the Grand Am, the Grand Am!" Lennie murmured beneath his breath. He found the stub of a pencil on the desk. ...

"Lennie, I meant what I said about no television," his mom called.

"I know you did."

"No television at all until those grades pick up."

"I know."

A commercial came on. "Doc-tor Pep-per, so misunder-stooooood."

Here we participate in Lennie's transit to and from the television world of the game show to that of his mother's demands. The TV program has the higher priority for the boy (the ultimate authorial message in the novel is that television is a poor substitute for human connections of peers and authorities). But in scenes like this there is no critical mediation of an adult; we enter Lennie's consciousness directly, moving with him in the halfhearted search for a pencil and then back again, and yet again to the game show world. We cross and recross to alternative loci. Psychologically, the individual enters the television world, then crosses back for interaction with someone else in the immediate environment, then recrosses to enter the television world again, this time an entirely different one as the program alternates with the commercial.

This alternation defines the so-called viewer as a figure continuously moving, a sojourner, a figure in transit between different TV worlds. This works in several ways. First, each single channel alternates program and commercial sequences, constantly moving the viewer out of one and into the other (e.g. 
from the game show to Doctor Pepper, from "Gilligan's Island" to the cat food.) Ostensible undivided attention to one channel is really a sojourning in and out of divers worlds, none of which has normative priority over any other.

As we see, moreover, in the fictional representation, the viewer is also pulled away from absorption in TV back into the surrounding habitat. The search for a pencil and the need to respond to a parent force Lennie to cross and recross a cognitive threshold from the habitat to the TV worlds and back again. "I know it's the Grand Am. ... I'm looking for a pencil. ... the Grand Am, the Grand Am!" Preference may lie as viewer with the TV world, but it is not possible to stay there. Others in the habitat claim attention. To meet the sensory demands, the individual must constantly move, adjust, accommodate, engage, withdraw to move again, etc.

And of course, since the mid-1960s the remote channel changer has made possible a viewer's participation in multiple TV worlds. To flip around the channels, themselves multiplied by the spread of multistation cable television systems, has become a common viewer experience. A press of a thumb takes one instantaneously from one world to another, and on to yet another. Thus the multiple realms within a single channel, compounded by distractions of the habitat and by the proliferation of channels and the hand-held device for channel changingall have created a viewer who is constantly moving and being moved.

No such figure appears in advertisements for television apparatus, which emphasize the power of the viewer to exercise control and choice. TV manufacturers and cable companies present their product and service as empowering the viewer with consumerist choices of sporting events, movies, music videos and sitcoms, not to mention the panoply of products. Their viewer is a figure of enthroned autonomy-discriminating, selecting, acquiring.

The cognitive reality, however, is actually the reverse. Mobility, not stable centrism, is the salient characteristic of the viewer. The structure of broadcast television in fact creates the viewer as sojourner, as a figure in transit. Accordingly, television-era fiction presents us with the protagonist in transit, in almost constant movement. And this movement is often irrelevant or, at best, only incidental to narrative development. It can seem random, defying conventional interpretive expectations of plot development, causal relationships, symbolic meanings, and the rest of fiction's characteristics. In Less than Zero, 
Bret Ellis's Clay, a southern California college boy, moves from freeway to poolside to bedroom to movie to cafe over and over again. Clay says,

After leaving Blair I drive down Wilshire and then onto Santa Monica and then I drive onto Sunset and take Beverly Glen to Mulholland, and then Mulholland to Sepulveda and then Sepulveda to Ventura and then I drive through Sherman Oaks to Encino and then into Tarzana and then Woodland Hills. I stop at Sambo's that's open all night and sit alone in a large empty booth. (61)

Or observe this, a typical passage from Beattie's Chilly Scenes of Winter, in which the protagonist, Charles, leaves work at day's end:

He goes through the revolving door and into the cold. His car is a long walk away. He turns on the cassette player he is holding in his other hand and "Folk Fiddling from Sweden" blares out. It is still playing when he gets to the car. The lock is frozen. He kicks it with his foot. Much to his surprise, the lock turns. He drives to a store and buys a large package of pork chops and a bag of potatoes and a bunch of broccoli and a six-pack of Coke. (73-74)

These novels certainly involve serious concerns: Charles is embroiled in family crises and obsessed with his lost love, Laura, while Clay learns horrible truths about a boyhood friend in a world of abdicated parental responsibility. Protagonists are shown in continual transit, whether over miles of freeway or within a room. The structure, however, of these narrations is of primary interest here because the profound issues in the TV fiction do not meet conventional expectations about the movement of fictional characters. Such expectations are even thwarted. Traditionally, the structure of mobility in fiction creates certain anticipations: the quest, the journey, the movement of the cycle of life signal embedded psychological development toward education, self-knowledge, identity formation. Yet movement in TV fiction frustrates such expectations because mobility per se is an environmental matrix of TV fiction. Movement is the cognitive modus vivendi. Thus these narratives do not enable, in fact do not permit, readers to interpret causal relationships, much less to see these loci in symbolic or metaphoric relation, or even in juxtapositions that elicit a sense of irony. Instead, the texts enact the experience of continuous flow. 
Because the contemporary consciousness experiences life in this way, these texts argue, the protagonist must be constructed as a figure in transit, and the reader also. Both are mobile figures, true to the cognitive experience of television. Transit, in and of itself, is the way of life, and therefore of art. The mobility of televisual "flow" is the fundament of fictional form.

Not surprisingly, this fluidity has struck critics as a certain aimlessness, shallowness, disengagement. William Gass decries the "epidemic" of the present tense in recent fiction, perceiving it to be symptomatic of cultural decline: "what could be expected of the pop population.... [of writers] expressing a self as shallow as a saucer?" (33). Another critic is equally negative: "We want plots; they give us plot summaries, much like those we might find in the pages of TV Guide" (Yagoda 30). This frustrated search for depth may indicate a misdirected search, one based on traditional, pre-TV-era premises about the relation of meaning to mobility in fiction.

Yet these censorious terms, targeted at the so-called new minimalism, can help us grasp another trait of TV-era fiction, namely, its formal response to the commercialism of broadcast television. Here we confront the conundrum of the writer for whom television is both the cognitive and the cultural environment. On the one hand, its fluidity mandates formal innovation in fiction, yet, on the other, its commercial summons jeopardizes the autonomy and integrity of the writer and the text. Commercialism invites uncritical assent, and the commercial nature of the medium potentially subverts the fictional world to which it responds. For in commercial terms, the writer is simply another viewer-consumer repeatedly manipulated into cravings that can only be temporarily satiated before new stimuli begin another cycle of desire. Resistance, as we know, is neither easy nor simple. The collective television context is one of "conventional values and consumer gratifications" (Gerbner et al. 446). Further, as Mark Miller points out, "What advertising needs is precisely what TV provides: a site secured against all threatening juxtaposition" and one which forecloses viewers' ironic critical distance with a built-in "prophylactic irony" that co-opts viewers with flattery $(13,15)$.

The novelists understand the jeopardy of TV commercialism. In Mason's In Country, the antiwar novel in which young Sam tries to learn the truth about her dead father's and her uncle's Vietnam experience, Sam watches "M*A*S*H" where "sometimes things were too simple" and she can "see right through them," though "it bothered her that it was so hard to find out the truth" $(83,70)$. Commercial television 
continuously offers "truth"; public officials and spokesmen for consumer products proffer endless versions of "the real thing." Beattie's protagonist, the apolitical Charles who earns his living working in a government bureaucracy, watches the evening news and sees former President Richard Nixon. "He looks like a lean old mafioso," thinks Charles, his form of expression unusually direct in this kind of narrative (116). These TV-era characters know that possibilities of seduction and betrayal lie everywhere. Updike expresses the shared view that "television goads them into begging for junk from the moment they open their eyes" (94).

For the TV-era writer, then, assent itself becomes problematic, since it is allied with commercial capitulation. Simply put, to commit oneself to any television realm as essential or authentic is to lose oneself. This is a contemporary, cognitive variation on the siren song: yield to the world of the cat food or the game show automobiles, and you forfeit something of yourself. As a child, Lennie might do so, but in maturity he must not. In fiction, the autonomy of the writer and the text therefore demands a lexicon that responds to television's commercialism without capitulating to it, and, at the same time, remains faithful to the cognitive sojourning within the TV environment.

The anticommercial discursive statement is only a small part of this self-preserving fictional lexicon. Far more significant is the diction that locates the psychological site of individual autonomy. The viewer, struggling to preserve integrity, pulls back when summoned to assent. The transit, the sojourning, brings the individual momentarily to the point of juncture between these many worlds of television and the habitat. Selfpossession becomes possible only at the moment and the place of crossover. Graphically, it is like the point at the center of an asterisk. Experientially, it is a threshold, the juncture between places. The viewer makes cognitive forays into the many television worlds, necessarily retreating to the neutral space of the juncture.

And there, at the point of juncture, a kind of autonomy is possible. To be sure, it is not a form ever acknowledged by broadcast television. Each and every TV world, from the cat food ad to the game show, to "Roots," "Dallas," "MacNeilLehrer," the Iran-Contra hearings, and the shopping network invites assent. Each is a Faustian bargain proffered in miniature. Integrity consists in refusing that assent, in exercising a form of passive resistance. Aggression takes this inverted form, and in 
TV fiction we must consider the diction that evokes this state of mind.

The terms privileged in this state are those of the tentative, the provisional. These are the terms that signal the effort to maintain integrity. In Todd Grimson's Within Normal Limits (1987) the protagonist, an emergency room physician, says, "Maybe things are clearer now than they ever have been before. I'm not sure. I'm not sure how much I should trust myself at the present time. . . . I don't know what ideal I might be after" (57, 142). In James Robison's The Illustrator (1988), the male narrator realizes his depth of feeling for a younger woman and says to himself, "I recognize the escalation of faith and terror that is, I guess, love. It's what I feel, maybe, I guess" (16). In The Sportswriter, arguably Richard Ford's one effort at the fiction of TV consciousness, the protagonist, Frank Bascombe, says he has forgotten where he wanted to go to college, "except it probably wasn't [Michigan]": "Does it seem strange that I do not have a long and storied family history? Or a list of problems and hatreds to brood about - a bill of particular grievances and nostalgias that pretend to explain or trouble everything? Possibly I was born into a different time. But maybe my way is better all around" $(28,29)$. We notice the recurrent phrases-"maybe," "I'm not sure," "probably," "possibly." The tentative, the provisional are the key terms, ones made explicit in the title of Peter Cameron's collection, One Way or Another, a phrase that refuses firm designation even at the cost of signaling moral indifference. These terms signal assent withheld, checked. To say, as some critics have, that this kind of style shows a lack of political, social or personal care or commitment misses the point because it really characterizes that commitment. In the era of commercial broadcast television, the voice of the tentative, the provisional is that of integrity. One analyst of these new writers complains that their prose is "stripped ... of formal awareness of itself" (Newman 25). On the contrary, this is prose exerting its power of self-preservation in the era of commercial broadcast television. Formally, in this sense, such prose is extremely self-aware.

The fictional form of the television aesthetic thus paradoxically enacts the traits of the medium and also rejects them. It resists the political-commercial marketplace summons even as it exploits the fluidity and presentism of the video experience. Ironically, its very resistance has elicited a grammar of the provisional and thereby altered the language of contemporary fiction. Nearly a quarter-century ago, in Understanding Media 
(1964), Marshall McLuhan observed what he called "the total involvement in all-inclusive nowness that occurs in young lives via TV's mosaic image" (335). He noted a "paradoxical feature" of the medium, namely, that "it involves us in moving depth, but does not excite, agitate or arouse" (337). In view of the attributes of much recent fiction, McLuhan's statements have proved prophetic, reaching beyond television to double back to Gutenberg's galaxy of the printed text.

\section{Works Cited and Consulted}

Allen, Robert C., ed. Channels of Discourse: Television and Contemporary Discourse. Chapel Hill: U of North Carolina P, 1987.

Speaking of Soap Operas. Chapel Hill: U of North Carolina P, 1985.

Anderson, Christopher. "Reflections on Magnum P.I." Television. The Critical View. Ed. Horace Newcomb. 4th edition. New York: Oxford UP, 1987. 112-25.

Attallah, Paul A. "The Unworthy Discourse: Situation Comedy in Television." Interpreting Television: Current Research Perspectives. Ed. William D. Rowland, Jr. and Bruce Watkins. Beverly Hills: Sage, 1984. 222-49.

Baudrillard, Jean. "The Ecstasy of Communication." The Anti-Aesthetic: Essays on Postmodern Culture. Ed. Hal Foster. Port Townsend, Washington: Bay Press, 1983. 12634.

Beattie, Ann. Chilly Scenes of Winter. 1976. New York: Warner, 1983.

Booth, Wayne C. "The Company We Keep: Self-Making in Imaginative Art, Old and New." Television: The
Critical View. Ed. Horace Newcomb. 4th edition. New York: Oxford UP, 1987. 382-418.

Bower, Robert T. The Changing Television Audience in America. New York: Columbia UP, 1985.

Byars, Betsy. The TV Kid. 1976. New York: Viking, 1987.

Carver, Raymond. Cathedral. New York: Vintage, 1984.

Dos Passos, John. Introduction. Three Soldiers. 1921. Boston: Houghton Mifflin, 1949.

Ellis, Bret Easton. Less than Zero. New York: Penguin, 1986.

Ellis, John. Visible Fictions: Cinema: Television: Video. London and Boston: Routledge \& Kegan Paul, 1982.

Feuer, Jane. "Narrative Form in American Network Television." High Theory/Low Culture. Ed. Colin MacCabe. New York: St. Martin's. 101-14.

Ford, Richard. The Sportswriter. New York: Vintage, 1986.

Gass, William H. "A Failing Grade 
for the Present Tense." The New York Times Book Review 11 Oct. 1987: 1, 32-35.

Gerbner, George, et al. "Charting the Mainstream: Television's Contributions to Political Orientations." American Media and Mass Culture: Left Perspectives. Ed. Donald Lazere. Berkeley: U of California P, 1987. 441-64.

Grimson, Todd. Within Normal Limits. New York: Vintage, 1987.

Hebert, Ernest. Whisper My Name. New York: Penguin, 1985.

James, Henry. Letters, Vol. IV, 18951916. Ed. Leon Edel. Cambridge: Harvard UP, 1987. 247.

Kaplan, E. Ann, ed. Regarding Television: Critical Approaches-An Anthology. Los Angeles: American Film Institute, 1983.

Rocking Around the Clock: Music Television, Postmodernism and Consumer Culture. New York: Methuen, 1987.

Kern, Stephen. The Culture of Time and Space 1880-1918. Cambridge: Harvard UP, 1983.

Lasch, Christopher. The Minimal Self: Psychic Survival in Troubled Times. New York: W. W. Norton, 1984.

Leavitt, David. Family Dancing. New York: Knopf, 1984.

MacCabe, Colin, ed. High Theory/ Low Culture: Analysing Popular Television and Film. New York: St. Martin's, 1986.

Martone, Michael. Safety Patrol. Baltimore: Johns Hopkins, 1988.
Mason, Bobbie Ann. In Country. New York: Harper and Row, 1986.

McCorkle, Jill. The Cheer Leader. New York: Vintage, 1986.

McLuhan, Marshall. Understanding Media: The Extensions of Man. New York and London. 1964.

Miller, Mark Crispin. Boxed In: The Culture of TV. Evanston: Northwestern UP, 1988.

Montagu, Ashley. "Television and the New Image of Man." The Eighth Art: Twenty-Three Views of Television Today. Ed. Robert Lewis Shayon. New York: Holt, Rinehart and Winston, 1962. 125-34.

Newman, Charles. "What's Left Out of Literature." The New York Times Book Review 12 July 1987: 1, 24-25.

Olmstead, Robert. Soft Water. New York: Vintage, 1988.

Robison, James. The Illustrator. New York: Summit, 1988.

Schivelbusch, Wolfgang. The Railway Journey: The Industrialization of Time and Space in the Nineteenth Century. 1977. Berkeley: U of California P, 1986.

Simpson, Mona. Anywhere but Here. New York: Vintage, 1986.

Updike, John. Roger's Version. New York: Ballantine, 1986.

Warner, William. "August 29, 1982 Bobst Library." ISBN. New York: Farrah, Upland, Westmoreland, and Granger, 1983.

White, Mimi. "Ideological Analysis and Television." Channels of Dis- 
course. Ed. Robert C. Allen. Chapel Wright, Lawrence. In the New World: Hill: U of North Carolina P, 1987. Growing Up with America 1960 134-71. 1984. New York: Knopf, 1988.

Williams, Raymond. Television: Yagoda, Ben. "No Tense Like the Technology and Cultural Form. New Present." The New York Times Book York: Schocken, 1975.

Review 10 Aug. 1986: 1, 30. 